rather more serious round the spring equinox than the autumn equinox, because, though the sun's altitude is the same, the temperature is lower, thus favouring a greater production of domestic smoke. Statistics are published on the degree of smoke-pollution at different times of the year; but no one who from suburban heights has habitually compared the visibility across London with the contemporaneous visibility in the opposite direction towards the open country will be under any illusion as to the relative importance of the smoke-screen in the summer and winter months. L. C. W. BONACINA.

27 Tanza Road, Hampstead, N.W.3, April 2I.

\section{On the Application of Science to the Fishing Industry.}

THE comments in NATURE of December $\mathrm{r}_{5}, \mathrm{I} 923$, p. 872 , on Prof. Stanley Gardiner's lecture on the above subject were read with interest. There is, indeed, much fault to be found with the operation of the fishing trade by any one of scientific training. In connexion with the statement that fishermen look askance at the mere mention of studying the plankton as a guide to placing fishing nets, however, it may be of interest to readers of NATURE to learn that plankton studies are rendering very material aid to the oyster industry in parts of the United States.

This industry, which yields approximately I6,000,000 dollars annually, is almost wholly dependent on the north-eastern Atlantic seaboard upon oyster seed collected on artificial cultch. In practice, oyster shells are usually employed for this purpose. The larvæ of the American oyster are pelagic for approximately two weeks, during which time they may be carried long distances by currents. It was shown by me in rgr 7 that the larvæ are not uniformly distributed in the water but are herded by slicks and eddies and by their own reactions into swarms. It was shown later by me, and by Churchill and Gutsell, of the U.S. Bureau of Fisheries, that the heaviest sets occur in those regions where the greatest numbers of swimming oyster larvæ are found to congregate.

It has been possible from examination of the water also to predict ten days in advance the date of an expected set with an error of less than thirty-six hours, thus serving as a guide to intensive last-minute shelling.

So far from being "left cold" by these findings, the oyster growers have been quick to seize upon this aid to their work, and they now actually demand this service from Federal and State governments. One of the larger planters of Long Island hired for two seasons a college student trained in this type of investigation, furnished him with microscope, pump, plankton net, and other necessary equipment, and employed his time during the oysters' breeding season in making tests on the private seed grounds of the company. The student in question has recently been taken into the company for full-time work, practical as well as scientific, throughout the entire year.

Some progress has been made in determining the probable fatness of oysters from a study of the food organisms present in the water. In the large oyster shipping centres, such as Delaware Bay, information of this nature is welcomed by the oyster growers even more than is knowledge of the distribution and age of the oyster larvæ. The chief difficulty in determining the abundance of food organisms in the water lies in the fact that about 80 per cent. of the oysters' food is composed of nannoplankton, the separation of which from water requires a high-speed electrically driven centrifuge, which cannot always be installed close enough to the oyster beds to carry on investiga- tions. The point of interest, however, is that the oyster growers understand the relation between the abundance of food organisms in the water and the fatness of oysters, thus appreciating the importance of plankton studies.

I have not had much contact with commercial fishermen, but from my slight acquaintance with them I have become convinced that many fishermen look upon men of science interested in fisheries as primarily conservationists, who are seeking to curtail the exploitation of certain species of fish, and must therefore be regarded with suspicion. This same attitude, much intensified, exists among the native oystermen along parts of our coasts.

In conclusion, I desire to point to the very cordial reception by oyster growers accorded to my father, the late Dr. Julius Nelson, during his investigations of the oyster from 1888 to I9I 5 in the United States and in Canadian waters, and to the same spirit which I have met since I9I5, as proof that among those who follow the sea for a livelihood there are some who can appreciate the contribution which a knowledge of the plankton may make to their calling.

$$
\text { Thurlow C. Netson. }
$$

Rutgers College,

New Brunswick, N.J., U.S.A. April 5.

\section{Hymenolepis nana and $H$. fraterna.}

Joyeux, in I920, after a survey of most of the evidence, arrived at the conclusion that Hymenolepis nana of man, and $H$. fraterna of rodents, though apparently indistinguishable in all characters, both of the adult worm and of the egg, are yet two distinct physiological species. More recently, however, two Japanese investigators, Saeki and Uchimura, have denied the validity of the experiments described by Joyeux, and affirm that it is possible to infect mice with $H$. nana eggs. The original papers of these two Japanese investigators not being easily accessible, and the brief abstracts available providing little or nothing of that detailed information which is so essential in these matters, I have recently been enabled, by the kind hospitality of Dr. A. Bettencourt, to re-examine the subject.

Briefly stated, I conveyed to Lisbon fifty-seven Hymenolepis fraterna free mice, thirty of which I have fed on fresh $H$. nana eggs obtained from the stools of infants in the hospital attached to the Instituto Camara Pestana, the remaining twenty-seven serving as controls. In the first batch of $H$. nana egg-fed mice, 2 were infected out of 10 ; in the second batch of I3, 4 were infected; and in the third batch of 7 , one only was infected. Thus 23 per cent. of the mice were infected - a result which is satisfactory in view of the fact that all the mice were adults, and therefore largely refractory to infection. The twentyseven control mice showed no signs of infection, and thus the possibility of accidental infection with $H$. fraterna is entirely excluded.

Saeki and Uchimura are therefore correct in their view that $H$. nana and $H$. fraterna are one and the same species (though the converse experiment of infecting monkeys or man with $H$. fraterna of mice and rats is still a desideratum), and doubtless man has become secondarily infected with a parasite which originally was associated with mice and rats alone.

Full details of the experiments referred to above will be published at an early date.

W. N. F. WOODLAND

(Helminthologist, Wellcome Burearu of Scientific Research).

Instituto Bacteriologico Camara Pestana, Lisboa, April 24.

NO. 2845 , VOL. I I 3$]$ 